\title{
ASPECTS OF CALORIC, NITROGEN AND MINERAL NUTRITION DURING GROWTH IN NESTLING EASTERN BLUEBIRDS, SIALIA SIALIS
}

\author{
Brian S. Hungerford, Eugene H. Studier*, Ernest J. Szuch, Gary L. Pace \\ and SUSAN TAYLOR \\ Department of Biology, University of Michigan-Flint, Flint, MI 48502-2186, U.S.A. (Tel. 313-762-3360)
}

(Received 9 December 1992; accepted 20 January 1993)

\begin{abstract}
Nestling eastern bluebirds experience a drop in live mass after 13 days of age; however, dry mass continues to increase.

2. Caloric density and body concentrations of $\mathrm{Fe}, \mathrm{Mg}$, and $\mathrm{Na}$ remain constant, $\mathrm{Ca}$ and $\mathrm{N}$ concentrations increase, and $\mathrm{K}$ concentration decreases with nestling age. Daily nutrient accretions in nestling eastern bluebirds are much less than in non-passerines.

3. Quantities of select insects fed to nestlings (to meet daily caloric requirements) do not satisfy certain elemental accretion requirements.

4. Fecal sac $\mathrm{Ca}$ levels indicate that nestlings scarcely receive a sufficient quantity of $\mathrm{Ca}$ to meet minimal growth requirements.
\end{abstract}

\section{INTRODUCTION}

Nutritional budgets involving nestling passerine birds are mostly limited to caloric economies (O'Conner, 1983; Ricklefs, 1984). Caloric economies are, however, only one aspect of nutrition associated with growth. In addition to caloric requirements, knowledge of nitrogen and mineral needs are required to understand nestling nutrition. With rare exceptions (Bilby and Widdowson, 1971; Hagen et al., 1976; Pinkowski et al., 1983; Taylor and Konarzewski, 1992), information about nitrogen and mineral requirements is presently available for only a limited number of granivorous, domestic, or game birds studied in captivity (National Research Council, 1984).

We analysed scavenged samples of eastern bluebirds, Sialia sialis, (an adult and known-aged nestlings, fecal sacs from known-aged nestlings, and abandoned eggs) for water, caloric, nitrogen, and mineral content to determine economies needed by a growing nestling. Live growth rates of nestlings were determined and dry growth rates were calculated from live growth rates and per cent body water determinations. Caloric, nitrogen, and mineral $(\mathrm{Ca}$, $\mathrm{Fe}, \mathrm{K}, \mathrm{Na}$ and $\mathrm{Mg}$ ) densities together with dry growth rates, were then used to estimate average and maximal rates of caloric and nutrient (total and daily) accretion.

A quantity of particular insects, normally fed to the nestlings by their parents, and sufficient to meet daily caloric requirements, may not satisfy certain other nutrient needs. Low fecal concentration of a mineral

*To whom all correspondence should be addressed. suggests that ingested food may be deficient in concentration of that nutrient, that maximal assimilation occurred, and that nestlings may be stressed for that particular element.

\section{MATERIALS AND METHODS}

Eastern bluebirds, Sialia sialis, were studied in Richfield County Park, Genesee Co., MI, during four breeding seasons (May through August from 1988 to 1991). Seventeen pairs of nest boxes were distributed throughout a field characteristic of eastern bluebird habitat. Nesting pairs were observed daily to determine the most common food items brought to nestlings. Nest boxes were opened daily to briefly observe and count eggs or young. Nestling birds were weighed between $8 \mathrm{a} . \mathrm{m}$. and $12 \mathrm{p} . \mathrm{m}$. every other day, using a Pesola $50 \mathrm{~g}$ spring scale, to generate a live growth curve for the first 16 days of the nestling period, with hatching termed day zero. As nestlings reach adult mass by the age of 16 days, we stopped handling them then to prevent premature fledging (normally fledge on day 19-21).

While monitoring growth rates of nestlings during the 1990 and 1991 breeding seasons, scavenged nestlings and adults, abandoned eggs, and nestling fecal sacs from known aged young were collected. Thirty one fecal sacs, 12 nestlings, one adult, and seven abandoned eggs were collected, sealed in plastic containers, and frozen for future analysis.

All samples were wet weighed (to $0.1 \mathrm{mg}$ ) and then dried to constant weight at $50-60^{\circ} \mathrm{C}$ to determine water content. Caloric density (reported as $\mathrm{Kcal} / \mathrm{g}$ dry mass) was obtained by creating pellets composed of benzoic acid and dried sample and burning the 
pellets in a Parr oxygen bomb calorimeter (Model 1300). Triplicate determinations for caloric density were performed on each sample. Mineral ( $\mathrm{Ca}, \mathrm{Fe}, \mathrm{K}$, $\mathrm{Na}$ and $\mathrm{Mg}$ ) and nitrogen concentrations (triplicate determinations) were determined after digesting dried samples in sulfuric acid followed by persulfuric acid and dilution with distilled water. Subsamples of these digestions were measured for mineral composition using a Varian Spectra AA-20 (Varian Techtron Ptg. Ltd., Springvale, Australia) atomic absorption spectrophotometer and are reported as parts per thousand dry mass (DM). Nitrogen levels were determined by Nesslerization and reported as parts per thousand DM. For details of these procedures, see Studier and Sevick (1992). Graphics were done using Delta Graph, data were stored as Lotus files, and statistics were done using Systat (Wilkinson, 1987).

\section{RESULTS AND DISCUSSION}

Live growth rates of nestling eastern bluebirds were monitored from hatching, day zero, through day sixteen, adult mass, (Fig. 1 upper panel) over the course of two breeding seasons. Polynomial regression analyses were used to describe the curvilinear relationship. Near day 13 and after, nestlings appear to lose live mass (LM). Nestling percentage body water remains constant at $82.25 \%$ until day 7 and then decreases linearly by $1.25 \%$ per day until day 16 when percentage body water is $71 \%$ and equivalent to adult levels. The dry growth curve (Fig. 1 lower panel), extrapolated from the live growth curve (based on percentage body water of each scavenged sample), shows that nestlings continue to deposit DM after day 13. Just prior to fledging, nestlings devote much energy to feather growth which deposits primarily dry weight and accounts for the decrease in LM. This loss in LM, as the bird approaches maturity, can then be explained by the drop in water content of the integument (Lack, 1968; O'Conner, 1983; Ricklefs, 1984).

Table 1 shows average caloric and elemental concentrations in the scavenged samples that were collected. Regression analyses indicate that the

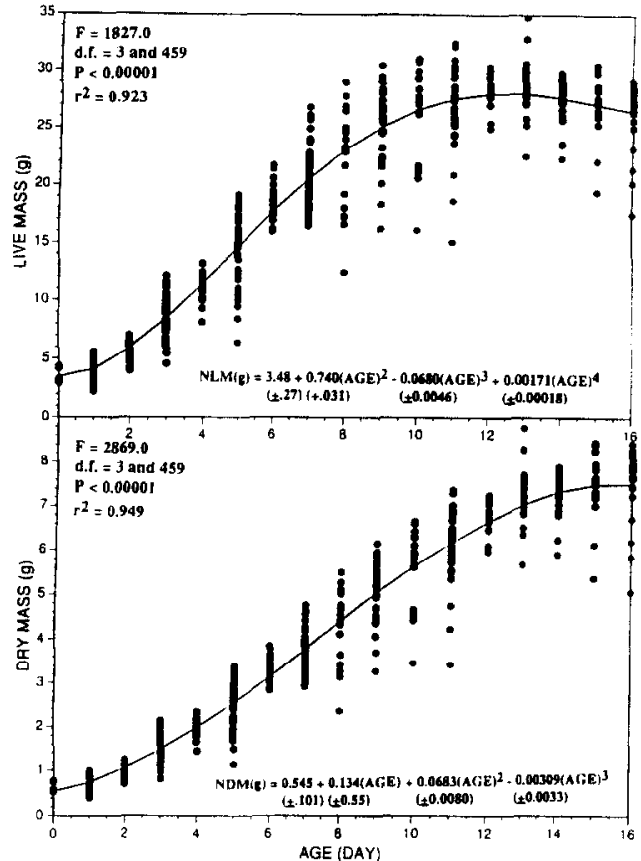

Fig. 1. Live growth (upper panel) and dry growth (lower panel) in known age nestling eastern bluebirds. Curves are produced from 463 weighings of 86 nestling ( 20 broods) Percentage body water in nestlings is constant at $82.25 \%$, through day 7 , and decreases linearly by $1.25 \%$ until day 16 . Dry mass is continually deposited, in contrast to live mass, as a result of rapid feather growth.

relationship between body nutrient concentration ( $\mathrm{Fe}, \mathrm{Mg}$ and $\mathrm{Na}$ ), in nestling tissues, and age, does not vary significantly in concentration with time (age of the nestling). Body nitrogen and calcium concentrations increase with nestling age, while concentration of potassium decreases with time (Tables 1, 2).

Figure 2 shows nestling total body nutrient content and nutrient accretion for $\mathrm{Na}, \mathrm{K}$ and $\mathrm{Ca}$. Nestling total body nutrient content was calculated using total DM for a particular day and nutrient concentration for that day, i.e. (total DM for each day in g) (nutrient concentration for each day in $\mathrm{mg} / \mathrm{g}$ ) $=$ total $\mathrm{DM}$ of nutrient for each day in mg. Total body $\mathrm{Na}$

Table 1. Caloric density (kcal/g dry mass $=\mathrm{DM}$ and $\mathrm{kcal} / \mathrm{g}$ ash-free dry mass $=$ AFDM) and elemental concentrations ( $\mathrm{mg} / \mathrm{g} \mathrm{DM}$ ) in eastern bluebird whole eggs, egg contents (embryos), nestlings, and an adult

\begin{tabular}{lllll}
\hline$N$ & $\begin{array}{c}\text { Whole egg } \\
\text { 3 }\end{array}$ & $\begin{array}{c}\text { Egg w/o shell } \\
4\end{array}$ & $\begin{array}{c}\text { Nestlings } \\
12\end{array}$ & $\begin{array}{c}\text { Adult } \\
1\end{array}$ \\
\hline kcal/g DM & $3842 \pm 228$ & $5033 \pm 55$ & $4161 \pm 68$ & 4133 \\
$\mathrm{kcal} / \mathrm{g}$ AFDM & $4590+259$ & $5226+54$ & $4330 \pm 82$ & 4335 \\
$\mathrm{Fe}$ & $0.328 \pm 0.003$ & $0.382 \pm 0.019$ & $0.214 \pm 0.011$ & 0.682 \\
$\mathrm{Ca}$ & $113.8 \pm 5.8$ & $20.89 \pm 1.22$ & $14.85 \pm 0.90^{*}$ & 35.90 \\
$\mathrm{Mg}$ & $1.111 \pm 0.145$ & $0.858 \pm 0.170$ & $1.300 \pm 0.034$ & 1.635 \\
$\mathrm{Na}$ & $13.39 \pm 1.81$ & $21.94 \pm 0.95$ & $10.84 \pm 0.25$ & 12.59 \\
$\mathrm{~K}$ & $14.15 \pm 0.29$ & $17.20 \pm 0.47$ & $15.74 \pm 0.94^{*}$ & 13.94 \\
$\mathrm{~N}$ & $90.81 \pm 3.00$ & $155.8 \pm 4.2$ & $148.2 \pm 2.1^{*}$ & 140.5 \\
\hline
\end{tabular}

Entries marked with an asterisk represent elements whose concentrations vary significantly with age of the nestling and regression analyses for these elements are given in Table 2. 
Table 2. Relationship of nitrogen, calcium, and potassium concentrations (in $\mathrm{mg} / \mathrm{g} \mathrm{DM}$ ) to age (in days), during growth in nestling eastern bluebirds, from hatching (day zero) through day 16

\begin{tabular}{lcccccc}
\hline Element & Reg. coeff. & Intercept & F & d.f. & $P$ & $r^{2}$ \\
\hline Nitrogen & $1.26 \pm 0.37$ & $135 \pm 4$ & 11.57 & 1,10 & 0.007 & 0.536 \\
Calcium & $0.606 \pm 0.135$ & $8.34 \pm 1.56$ & 20.14 & 1,10 & 0.001 & 0.668 \\
Potassium & $-0.605 \pm 0.153$ & $22.2 \pm 1.8$ & 15.53 & 1,10 & 0.003 & 0.608 \\
\hline
\end{tabular}

Values shown are means $\pm \mathrm{SE}$.

level for a 6 day-old nestling, for example, is $(3.14 \mathrm{~g}$ DM) $(10.84 \mathrm{mg} / \mathrm{g} \mathrm{DM})=34.04 \mathrm{mg} \mathrm{Na}$. Total body nutrient levels for $\mathrm{Na}, \mathrm{K}$ and $\mathrm{Ca}$, and their changes with age of the nestling, are illustrated by the three curves in the main body of Fig. 2. Since $\mathrm{Ca}$ and $\mathrm{K}$ both vary in concentration with age of the nestling (while Na remains constant) resultant curves all have a similar sigmoidal shape but different inflexion points (days), which are evidenced in age related changes in daily nutrient accretion (Fig. 2 insert). Accretion of nutrients for each day was calculated from change in DM for a particular day and nutrient concentration for that day, i.e. (change in DM for each day in $\mathrm{g} /$ day) (nutrient concentration for each day in $\mathrm{mg} / \mathrm{g}$ ) $=$ accretion of nutrient for each day in $\mathrm{mg} /$ day. Sodium accretion in the tissues of a 6 day-old nestling, for example, is $(0.60 \mathrm{~g} /$ day $)$ $(10.84 \mathrm{mg} \mathrm{Na} / \mathrm{g})=6.50 \mathrm{mg} \mathrm{Na} /$ day.

Daily nutrient accretion increases daily to a maximum and thereafter nutrient accretion continues but at a slower rate. Because $\mathrm{Ca}$ becomes more concentrated in nestling tissues with time, the day on which maximal accretion occurs is later than with $\mathrm{Na}$ which remains constant in concentration with time. Peak accretion for $\mathrm{K}$ occurs earlier (at a younger age) because $\mathrm{K}$ decreases in concentration with time. Regression equations for daily accretion rates and total accretion of each measured nutrient are given in Table 3.

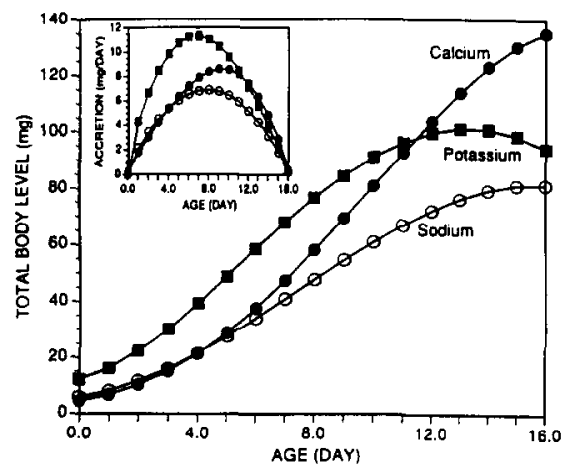

Fig. 2. Total body nutrient content (main body) and nutrient accretion (insert) for $\mathrm{Na}, \mathrm{K}$, and $\mathrm{Ca}$ in nestling eastern bluebirds. $\mathrm{Ca}$ and $\mathrm{K}$ vary in concentration with age of the nestling (giving a different inflexion point) while $\mathrm{Na}$ remains constant. All three nutrients have a sigmoidal shaped curve as they are based on the same dry growth curve (see text for calculations). Peak accretion for each nutrient also occurs on a unique day based again on the fact that $\mathrm{Ca}$ and $\mathrm{K}$ vary in concentration and $\mathrm{Na}$ remains constant with age of the bird.
Average and maximal rates of nutrient and caloric accretion (as well as the day on which maximal accretion occurs) are calculated from accretion curves in Table 3 and are shown in Table 4. Three common food items brought to nestlings by adult nesting pairs are grasshoppers (Melanoplus sp.), crickets (Gryllus sp.), and lepidopteran larvae. Caloric, nitrogen and mineral concentrations of average sized grasshoppers and crickets, have been determined (Studier and Sevick, 1992). Lepidopteran larvae caloric and mineral composition data were taken from Carter and Cragg (1976) and Levy and Cromroy (1973).

Table 4 shows the above three food items and quantities of each required to meet average and maximal daily rates of caloric, nitrogen and mineral accretion. Kcal (total) is based on total caloric requirements for nestling house sparrows, Passer domesticus (Blem, 1975). Eastern bluebirds and house sparrows are similar sized passerine birds with nestling periods of comparable duration. If fed a quantity of grasshoppers that meets their average daily caloric requirement $(4.21 \mathrm{~g} \mathrm{DM}=98.1$ grasshoppers), $\mathrm{Na}$ accretion requirement $(14.0 \mathrm{~g}$ $\mathrm{DM}=326.0$ grasshoppers) of nestlings is not satisfied. Similarly, $4.21 \mathrm{~g} \mathrm{DM} \mathrm{(251.0} \mathrm{male} \mathrm{crickets)} \mathrm{are}$ needed to meet nestling daily caloric requirement, if the nestlings are being fed crickets only. The calcium requirement for daily accretion is greater (4.55 g DM $=271.0$ crickets) and will not be met. Eating lepidopteran larvae exclusively to satisfy average daily caloric needs would result in an $\mathrm{Fe}$ deficiency.

Table 5 shows average minimal growth requirements (nitrogen and mineral nutrients) for nestling eastern bluebirds (at two different assimilation efficiencies), leghorn-type chickens, turkeys, Japanese quail and Pekin ducks. Average fecal sac concentrations for nitrogen and mineral nutrients are also shown. Nutrient requirements have been generated for bluebirds at assimilation efficiencies of 100 and $65 \%$. Although requirements of bluebirds compare favorably to those of other feral birds (see Taylor and Konarzewski, 1992) $\mathrm{Fe}, \mathrm{Ca}, \mathrm{Mg}$ and $\mathrm{K}$ are required in greater concentration by the domestic, grain eating birds when compared to bluebirds. Na requirements are similar and $\mathrm{N}$ is required in much greater concentration by the grain eating birds. Rapid growth and muscle development are of primary concern when raising domestic grain eating birds in captivity, which may explain the large difference in nitrogen requirements between both types of birds. Greater require- 
Table 3. Polynomial regression coefficients for daily (mg/day; except energy $=\mathrm{Kcal} / \mathrm{day})$ and total (mg; except $N-\mathrm{g}$ and energy = Kcal) nutrient accretion in nestling (days 0 through 16) eastern bluebirds, where age is in days

\begin{tabular}{|c|c|c|c|c|c|}
\hline \multicolumn{2}{|c|}{ Intercept } & \multicolumn{4}{|c|}{ Coefficients } \\
\hline Nutrient & & age & age $^{2}$ & $\mathrm{age}^{3}$ & $\mathrm{age}^{4}$ \\
\hline \multicolumn{6}{|c|}{ Daily accretion rate } \\
\hline $\mathrm{Fe}$ & +0.00771 & +0.0326 & -0.00205 & - & - \\
\hline $\mathrm{Ca}$ & +0.249 & +1.36 & - & -0.00526 & - \\
\hline $\mathbf{M g}$ & +0.0469 & +0.198 & -0.0125 & - & - \\
\hline $\mathrm{Na}$ & +0.391 & +1.65 & -0.104 & - & - \\
\hline $\mathrm{K}$ & +0.521 & +3.60 & -0.342 & +0.00728 & - \\
\hline $\mathrm{N}$ & +0.0906 & +2.21 & +2.13 & -0.289 & +0.00921 \\
\hline Kcal & +0.150 & +0.633 & -0.0399 & - & - \\
\hline \multicolumn{6}{|c|}{ Total accretion } \\
\hline $\mathrm{Fe}(\mathrm{T})$ & +0.117 & +0.0286 & +0.0146 & -0.00066 & - \\
\hline $\mathrm{Ca}(\mathrm{T})$ & +5.71 & -0.562 & +1.26 & -0.0443 & - \\
\hline $\operatorname{Mg}(T)$ & +0.708 & +0.174 & +0.0888 & -0.00402 & - \\
\hline $\mathrm{Na}(\mathrm{T})$ & +5.91 & +1.45 & +0.740 & -0.0335 & - \\
\hline$K(T)$ & +10.9 & +4.65 & +0.834 & -0.0502 & - \\
\hline$N(T)$ & +0.0758 & +0.0145 & +0.0106 & -0.00045 & - \\
\hline Kcal(T) & +2.27 & +0.556 & +0.284 & -0.0129 & - \\
\hline
\end{tabular}

Table 4. Average (= Mean $\pm \mathrm{SE}, N=16$ ) and maximal (MAX) rates of nutrient accretion [nutrients in $\mathrm{mg} /$ day and Kcal(growth) in $\mathrm{Kcal} / \mathrm{day}$ ] at a food caloric density of $4.5 \mathrm{Kcal} / \mathrm{g} \mathrm{DM}$ during the period from hatching (day zero) through day 16 in nestling eastern bluebirds

\begin{tabular}{|c|c|c|c|c|c|c|c|c|}
\hline Nutrient & $\begin{array}{c}\text { Mean } \\
(\mathrm{mg} / \text { day })\end{array}$ & $\begin{array}{c}\text { Max } \\
(\mathrm{mg} / \text { day })\end{array}$ & $\begin{array}{c}\text { Age } \\
\text { (days) }\end{array}$ & & Melanoplus & Gryllus (M) & Gryllus (F) & $\begin{array}{c}\text { Lepidoptera } \\
\text { (larvae) }\end{array}$ \\
\hline $\mathrm{Fe}$ & $0.093 \pm 0.010$ & 0.137 & 7.9 & $\mathrm{DM}(\mathrm{g})$ & $\begin{array}{l}0.26(0.38) \\
6.0(8.9)\end{array}$ & $\begin{array}{l}1.03(1.52) \\
61.5(90.6)\end{array}$ & $\begin{array}{l}0.55(0.81) \\
15.1(22.2)\end{array}$ & $4.43(6.52)$ \\
\hline $\mathrm{Ca}$ & $5.718 \pm 0.634$ & 8.667 & 9.3 & $\mathrm{DM}_{*}(\mathrm{~g})$ & $\begin{array}{c}2.62(3.97) \\
61.0(92.5)\end{array}$ & $\begin{array}{r}4.55(6.90) \\
271.0(411.0)\end{array}$ & $\begin{array}{c}1.73(2.62) \\
47.6(72.1)\end{array}$ & $2.93(4.44)$ \\
\hline $\mathbf{M g}$ & $0.566 \pm 0.060$ & 0.831 & 7.9 & DM $(\mathrm{g})$ & $\begin{array}{l}0.35(0.50) \\
8.1(11.9)\end{array}$ & $\begin{array}{c}0.52(0.76) \\
30.9(45.3)\end{array}$ & $\begin{array}{c}0.39(0.57) \\
10.7(15.7)\end{array}$ & $0.44(0.64)$ \\
\hline $\mathrm{Na}$ & $4.716 \pm 0.497$ & 6.934 & 7.9 & $\mathrm{DM}(\mathrm{g})$ & $\begin{array}{c}14.0(20.6) \\
326.0(480.0)\end{array}$ & $\begin{array}{r}1.85(2.72) \\
110.0(162.0)\end{array}$ & $\begin{array}{c}2.14(3.14) \\
58.8(86.5)\end{array}$ & $2.82(4.15)$ \\
\hline $\mathbf{K}$ & $7.589 \pm 0.839$ & 11.478 & 6.7 & $\mathrm{DM}(\mathrm{g})$ & $\begin{array}{c}0.63(0.96) \\
14.8(22.3)\end{array}$ & $\begin{array}{c}0.42(0.63) \\
25.0(37.7)\end{array}$ & $\begin{array}{c}0.51(0.77) \\
13.9(21.1)\end{array}$ & $0.34(0.50)$ \\
\hline $\mathbf{N}$ & $24.163 \pm 3.741$ & 43.869 & 7.9 & $\mathrm{DM}_{*}(\mathrm{~g})$ & $\begin{array}{l}0.14(0.25) \\
3.2(5.9)\end{array}$ & $\begin{array}{l}0.14(0.26) \\
8.5(15.5)\end{array}$ & $\begin{array}{l}0.16(0.29) \\
4.3(7.9)\end{array}$ & \\
\hline Kcal (growth) & $1.810 \pm 0.191$ & 2.659 & 7.9 & $\mathrm{DM}(\mathrm{g})$ & $\begin{array}{l}0.40(0.59) \\
9.4(13.8)\end{array}$ & $\begin{array}{c}0.40(0.59) \\
23.9(35.2)\end{array}$ & $\begin{array}{l}0.40(0.59) \\
11.1(16.3)\end{array}$ & $0.31(0.46)$ \\
\hline Kcal (total) & $19.038+1.628$ & 27.968 & 7.9 & $\mathrm{DM}(\mathrm{g})$ & $\begin{array}{r}4.21(6.21) \\
98.1(145.0)\end{array}$ & $\begin{array}{r}4.21(6.21) \\
251.0(369.0)\end{array}$ & $\begin{array}{r}4.21(6.21) \\
116.0(171.0)\end{array}$ & $3.29(4.83)$ \\
\hline
\end{tabular}

Total daily energy requirements [Kcal (total) in Kcal/day], based on house sparrow requirements (Blem, 1975), are given at the bottom of the table. Calculated day $(=\mathrm{AGE}$ ) on which maximal nutrient accretion occurs is also shown. For several foods frequently brought by parents to the nestlings, insect dry mass (DM) required to meet mean and maximal (in parentheses) daily individual accretion requirements (at $100 \%$ assimilation efficiency) and number ${ }^{*}$ of individual insects of average dry mass are given. Data on insect composition (grasshoppers and crickets) are from Studier and Sevick (1992). Grasshoppers (Melanoplus) include, at least, M. femurrubrum, M. borealis, and $M$. confusus $(N=107$, mean $\mathrm{DM}=42.9 \mathrm{mg}$ ). Crickets are male $(\mathrm{M})$ and female (F) Gryllus pennsylvanicus (for male: $N=11$, mean $\mathrm{DM}=16.8 \mathrm{mg}$; for female: $N=17$, mean $\mathrm{DM}=36.3 \mathrm{mg}$ ). Data on lepidopteran larvae composition are from Carter and Cragg (1976) and Levy (1973) [nutritional calculations for $\mathrm{Mg}, \mathrm{Na}$, and $\mathrm{K}$ are based on averages generated from the two papers, $\mathrm{Ca}$ calculations are from Carter and Cragg (1976) and Fe calculations are from Levy and Cromroy (1973)].

Table 5. Average minimal growth requirements ( $\mathrm{mg} / \mathrm{g}$ dry food mass) for nitrogen and mineral nutrients in nestling eastern bluebirds at $100 \%$ and $65.5 \%$ caloric assimilation efficiencies, assuming food caloric density of 4.0 and $5.0 \mathrm{kcal} / \mathrm{g}$ dry mass

\begin{tabular}{|c|c|c|c|c|c|c|c|}
\hline \multirow[b]{2}{*}{ Nutrient } & \multicolumn{2}{|c|}{ Eastern bluebird } & \multirow[b]{2}{*}{ Chicken } & \multirow[b]{2}{*}{ Turkey } & \multirow[b]{2}{*}{ J. quail } & \multirow[b]{2}{*}{ P. duck } & \multirow{2}{*}{$\begin{array}{c}\text { Fecal sacs } \\
(N=31)\end{array}$} \\
\hline & (@100\% AE) & (@65.5\% AE) & & & & & \\
\hline$\overline{\mathrm{Fe}}$ & $0.022-0.027$ & $0.034-0.042$ & $0.06-0.08$ & $0.05-0.08$ & 0.10 & & $0.542 \pm 0.078$ \\
\hline $\mathrm{Ca}$ & $1.25-1.56$ & $1.92-2.40$ & $6.0-8.0$ & $5.5-12.0$ & 8.0 & 6.5 & $2.368 \pm 0.719$ \\
\hline $\mathbf{M g}$ & $0.13-0.16$ & $0.21-0.26$ & $0.4-0.6$ & 0.6 & 0.3 & 0.5 & $2.826 \pm 0.155$ \\
\hline $\mathrm{Na}$ & $1.10-1.37$ & $1.71-2.13$ & 1.5 & $1.2-1.7$ & 1.5 & 1.5 & $6.054 \pm 0.568$ \\
\hline K & $1.85-2.31$ & $2.90-3.62$ & $2.5-4.0$ & $4.0-7.0$ & 4.0 & & $28.76+1.49$ \\
\hline $\mathbf{N}$ & $5.26-6.58$ & $8.06-10.08$ & $19.2-28.9$ & $22.4-44.8$ & 38.4 & $25.6-35.2$ & $215.5 \pm 6.6$ \\
\hline
\end{tabular}

Also shown are minimal growth requirements for leghorn-type chickens, turkeys, Japanese quail (Coturnix), and Pekin ducks (all from National Research Council, 1984). Levels ( $\mathrm{mg} / \mathrm{g}$ dry mass) of measured nutrients (mean $\pm S E$ ) in fecal sacs of nestling eastern bluebirds (aged 5 to 16 days) are also shown. 


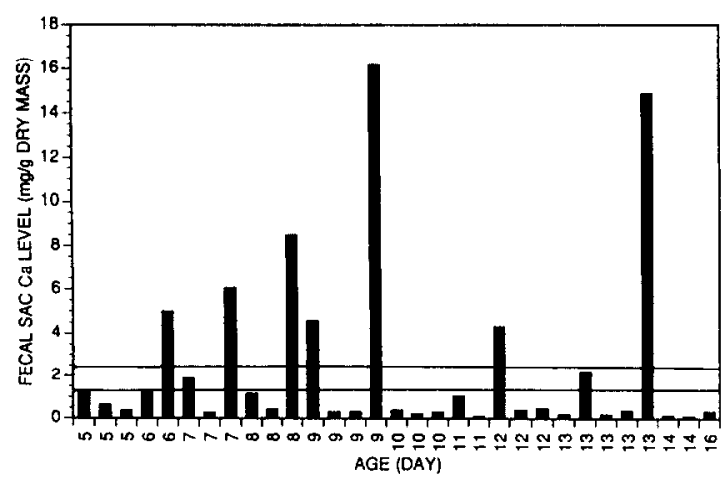

Fig. 3. Known age nestling fecal sac concentrations $(N=31)$ for $\mathrm{Ca}$. The horizontal box represents the range of $\mathrm{Ca}$ needed $(1.25-2.40 \mathrm{mg} / \mathrm{g}$ dry food mass) as shown in Tablc 5. See text for further information.

ments for other nutrients in domesticated birds may reflect general selection for rapid growth in such birds or may reflect long term adaptations to general dietary composition which certainly differ in granivorous vs insectivorous birds.

Fecal sac nutrient concentrations for the bluebirds are higher than ingested nutrient requirements for all the nutrients except $\mathrm{Ca}$ (Table 5). This suggests that nestlings are fed all measured nutrients, except $\mathrm{Ca}$, in amounts which exceed requirements. Fecal concentration of $\mathrm{Ca}$, however, falls within the upper range of need for food $\mathrm{Ca}$ concentration for the nestlings. Nestlings, therefore, may not be fed an adequate dietary concentration of $\mathrm{Ca}$ by the parents. Calcium has been suggested as a growth limiting nutrient for nestling feral birds (Bilby and Widdowson, 1971; Turner, 1992).

Figure 3 represents $\mathrm{Ca}$ concentration in 31 individual fecal sacs taken from known age nestling birds. The average Ca concentration $[2.37 \pm 0.72$ (SE) $\mathrm{mg}$ $\mathrm{Ca} / \mathrm{g} \mathrm{DM}$ ] from all 31 fecal sacs, also shown in Table 5, is represented by the upper line to the horizontal box. Twenty-two of the 31 fecal sacs analysed for $\mathrm{Ca}$, fall below the range of need for growth in the nestling birds. Most food items, therefore, are inadequate sources of $\mathrm{Ca}$. Occasionally, however, nestlings are being fed food items that are extremely high in $\mathrm{Ca}$, yielding seven fecal sacs that have a $\mathrm{Ca}$ concentration well above the nestlings' growth requirement. These seven fecal sacs shift the average fecal sac level to just below the upper range of requirement. While most insects are inadequate or barely adequate $\mathrm{Ca}$ sources, snails and non-insect arthropods such as millipedes and sowbugs, may provide the very rich $\mathrm{Ca}$ sources fed occasionally to nestlings (Reichle et al., 1969;
Carter and Cragg, 1976; Levy and Cromroy, 1973; Pinkowski, 1978).

Acknowledgements-This study was supported by grants from the Faculty Development Fund of The University of Michigan-Flint and Genesee Audubon, Inc. We gratefully acknowledge Genesee County Parks and Recreation Commission for providing the study site. We thank Beth Ann Szuch, Colleen Pace, Michele Cyr, Michele Renaud, Steve Stoddard, Susan Handa and Kirk Weil for assisting with field work. We thank Dr Mark Brigham for useful and insightful comments on the manuscript.

\section{REFERENCES}

Bilby L. W. and Widdowson E. M. (1971) Chemical composition of growth in nestling blackbirds and thrushes. Br. J. Nutr. 25, 127-134.

Blem C. R. (1975) Energetics of nestling house sparrows, Passer domesticus. Comp. Biochem. Physiol. 52A, 305-312.

Carter A. and Cragg J. B. (1976) Concentrations and standing crops of calcium, magnesium, potassium, and sodium in soil and litter arthropods and their food in an aspen woodland ecosystem in the Rocky Mountains (Canada). Pedobiologia 16, 379-388.

Hagen J., IIagen A., Ostbye E. and Skar H.-J. (1976) Some chemical elements in the body of the meadow pipit, Anthus pratensis (L.). Norweg. J. Zool. 24, 279-289.

Lack D. (1968) Ecological Adaptations for Rreeding in Birds. Methuen, London.

Levy R. and Cromroy H. L. (1973) Concentration of some major and trace elements in forty-one species of adult and immature insects determined by atomic absorption spectroscopy. Ann. Ent. Soc. Am. 66, 523-526.

National Research Council (1984) Nutrient Requirements of Poultry. 8th revised edn, National Academy of Sciences, Washington, D.C.

O'Conner R. J. (1983) The Growth and Development of Birds. John Wiley \& Sons, New York.

Pinkowski B. C. (1978) Feeding of nestling and fledgling eastern bluebirds. The Wilson Bulletin. 90, 84-98.

Pinkowski J., Pinkowski B., Krasnicki K. and Tomek T. (1938) Chemical composition of growth in nestling rooks Corvus frugilegus. Ornis Scand. 14, 289-298.

Reichle D. E., Shanks M. H. and Crossley D. A. (1969) Calcium, potassium, and sodium content of forest floor arthropods. Ann. Ent. Soc. Am. 62, 57-62.

Ricklefs R. E. (1984) Avian post-natal development. In Avian Biolngy (Edited Farner D. S., King J. R. and Parkes K. L.), Vol. VII, pp. 1-83. Academic Press, New York.

Studier E. H. and Sevick S. H. (1992) Live mass, water content, nitrogen, and mineral levels in some insects from south-central lower Michigan. Comp. Biochem. Physiol. 103A, 579-596.

Taylor J. R. E. and Konarzewski M. (1992) Budget of elements in little auk (Alle alle) chicks. Funct. Ecol. 6, 137-144.

Turner A. K. (1982) Timing of laying by swallows (Hirundo rustica) and sand martins (Riparia riparia). J. Anim. Ecol. 51, 29-46.

Wilkinson L. (1987) SYSTAT: The system for statistics. SYSTAT Inc., Evanston, IL. 